\title{
TAXATION OF TRANSFERS IN CONTEMPLATION OF DEATH: A PROPOSAL FOR ABOLITION
}

\author{
EDMUND W. PAVENSTEDT $\dagger$
}

WHEN a tax statute has been in effect for almost thirty years, has been considered by the courts in more than two hundred and fifty instances, ${ }^{1}$ and its meaning is still so unsettled as to produce contrary results in almost identical cases, ${ }^{2}$ there would seem to be little excuse for further delay in curing the situation either by drastic amendment or by outright repeal. This should be even more true where the Government's record of successful litigation has been consistently poor, as a result of which it has presumably been driven in recent years to the expedient of interpreting the provision in a manner going far beyond the test laid down by the Supreme Court. And, finally, there is crying need for a change because, as attorneys engaged in estate tax matters know and as even revenue officers will occasionally admit in private conversation, the threat of the provision is often invoked in negotiations for settlements of estate tax liability primarily for trading purposes with respect to transfers quite clearly not within the ambit of the statute.

This harsh indictment is directed at the provision taxing transfers made in contemplation of death. It was incorporated in the Federal Estate Tax Law of $1916^{3}$ in the following language which remains substantially unchanged in the currently effective section of the Internal Revenue Code ${ }^{4}$ :

"That the value of the gross estate of the decedent shall be determined by including the value at the time of his death of all property, real or personal, tangible or intangible, wherever situated, . . . to the extent of any interest therein of which the decedent has at any time made a transfer, or with respect to which he has created a trust, in contemplation of ... his death, except in case of a bona fide sale for

$\dagger$ Member, District of Columbia and New York Bars, formerly Special Assistant to the Attorney General, Tax Division, Department of Justice.

1. All of the statistics in this article and much of its subject matter have been taken from two papers, privately published, on the taxability under federal law of transfers made in contemplation of death, by Walter S. Orr, Esq., member of the New York bar. The author of this article assisted Mr. Orr in the preparation of the latter of these papers.

2. Compare, e.g., Mary E. Barnard, C. C. H. Dec. 11,318-B (BTA mem. 1940) with Alice B. Davis, C. C. H. Dec. 12,943-E (TC mem. 1943). See discussion of these cases, infra pp. 84-5.

3. Revenue Act of $1916, \S 202(\mathrm{~b})$. For a comprehensive study of the provision, see Paul, Federal Estate and Gift Taxation (1942) c. 6.

4. Section 202(b), loc. cit. supra note 3. For the present section, see INT. REV. CODE, § 811 (c) (1939). 
a fair consideration in money or money's worth. Any transfer of a material part of his property in the nature of a final disposition or distribution thereof, made by the decedent within two years prior to his death without such a consideration, shall, unless shown to the contrary, be deemed to have been made in contemplation of death within the meaning of this title."

As might have been expected, a provision depending upon a determination of the intent of a dead person proved extremely difficult to administer. ${ }^{5}$ Hence, for some years, beginning with the Revenue Act of 1926. the law was changed to provide that all transfers to any one person in excess of $\$ 5,000$ made without adequate consideration within two years of death should be "deemed and held" to have been made in contemplation of death. ${ }^{6}$ But the Supreme Court in Heiner a'. Domuam. ${ }^{7}$ with Justices Stone and Brandeis dissenting and Justice Cardozo not taking part in the consideration of the case, held this conclusive presumption unconstitutional.

The law thereupon reverted to the rebuttable two-year presumption, ${ }^{8}$ affecting all transfers of a "material part" of a transferor's property. Such a presumption would seem to add little to the customary presumption in favor of the correctness of any determination made by the Commissioner. Statistics indicate that it is rather meaningless. In those litigated cases in which the time intervening between the challenged transfer and death is stated, the Government has been successful in 95 , in 32 of which the interval was longer than two years. On the other hand, it has lost 132 decisions where the transfer was made within the period of the presumption. As far as concerns the vague requirement that the transfer must be of a "material part" of the decedent's property, the 137 cases which mention the proportion of the gift to the total estate show the following meaningless results :

Gifts held to be sot in contcmplation of death

Less than $10 \%$
$10 \%$ to $20 \%$
$20 \%$ to $40 \%$.
$40 \%$ to $60 \%$
$60 \%$ to $70 \%$
$70 \%$ to $80 \%$
$80 \%$ to $90 \%$
$90 \%$ to $99 \%$
$100 \%$

Gifts held to be in contemplation of death

$\begin{array}{rr}8 & 3 \\ 21 & 3 \\ 18 & 8 \\ 21 & 12 \\ 6 & 3 \\ 3 & 0 \\ 8 & 0 \\ 6 & 4 \\ 8 & 5\end{array}$

5. See Mrr. Justice Stone's dissent in Heiner v. Dünan, 285 C. S. $312,332,342-7$ (1932).

6. Revenue Act of $1926, \S 302(c)$.

7. 285 U. S. 312 (1932).

8. Revenue Act of $1932, \S 803(\mathrm{a})$, amending Revenue Act of $1925, \S 302(\mathrm{c})$. 
These statistics indicate that the statutory rebuttable presumption has not been of any great aid to the Treasury.

A final glance at statistics discloses that the Government's record in contemplation of death cases, although showing marked improvement in recent years in tribunals other than the Tax Court, can hardly be satisfactory from its point of view. From 1920 through 1933 the Government's score was:

2 won in circuit courts of appeals as against 5 lost,

4 won in district courts as against 20 defeats, and

2 won and 3 lost in the Court of Claims,

or 8 victories and 28 defeats, or $22 \%$ won. From 1934 through 1938 there was some improvement with:

5 won in circuit courts of appeals as against 7 lost,

6 won in district courts as against 13 defeats, and

3 won and 2 lost in the Court of Claims, or 14 victories and 22 defeats, a winning percentage of 39 . During the five years ending with 1943 the Government raised this to $43 \%$ with:

6 won and 4 lost in circuit courts of appeals,

6 won and 14 lost in district courts, and

3 won and 2 lost in the Court of Claims, totalling 15 victories against 20 defeats.

In the Tax Court the Government's record is even worse. ${ }^{0}$ During the nine years ending with 1933 it won 16 cases out of 60 , or less than $27 \% .^{10}$ From 1934 through 1938 it won only 6 out of 53, or $11 \%$, and in the next five years it won 12 out of 63 , or $19 \%$, plus 3 decisions in which it scored partial victories.

In 1944 the Government won 5 and lost 3 cases in the circuit courts of appeals, won 1 case in the district courts as against 5 lost, and was successful before the Tax Court in 4 cases out of 11 , for a total of 10 victories 'and 15 defeats. ${ }^{11}$ However, the 1943 statistics were quite unfavorable to the Government, showing. 7 victories and 18 defeats. ${ }^{12}$ It is, therefore, impossible to find a consistent trend running in favor of the

9. In this connection it is interesting to note that seven of the sixteen judges of the Tax Court were originally appointed to the Board prior to March 4, 1933.

10. The figures for the period before 1934 do not include Memorandum Opinions, but these were relatively scarce at that time. The statistics for 1934-1938 show that of 53 cases. 29 were decided on Memorandum Opinions; during 1939-1943 Memorandum Opinions disposed of 39 out of 62 cases.

11. These figures do not include one circuit court of appeals decision affirming a 1944 victory in the Tax Court.

12. Circuit courts of appeals, 3-1; district courts, 1-6; Court of Claims, 0-0; Tax Court, 3-11; or, in the aggregate, 7 victories against 18 defeats. In addition, the Government was partially successful in 2 other Tax Court cases. 
Government, or to conclude either that the Bureau has in recent years been more inclined to settle doubtful cases or that the courts have been stricter with the taxpayer when determining whether his decedent transferred property in contemplation of death. ${ }^{13}$

In view of this rather discouraging record it is perhapls not surprising that the Government should have attempted to tighten its regulations with respect to the meaning of what constitutes "contemplation of death." What is, or perhaps more accurately, what should be surprising, is that this revision of the proper criterion seems to fly in the face of the test established by the Supreme Court.

\section{Developaient of Norms to Deteraine Mutivitions of TRANSFERS}

The Rule of United States $\pi$. Wells. In the relatively rare case where it can be established that a transfer was induced by only one cause, either by $a$ motive associated with life or by thought of death, decision would seem

13. It may be noted that in recent years far greater weight has lisen given to the decisions of the triers of the facts. Of the "contemplation of death" cases dccidcl yrior to 1939, 12 district court and 12 Board of Tax Appeals decisions were arpealed and $t$ of each were reversed. 4 of these 24 circuit court of appeals decisiuns were reviewed by the Supreme Court, but that Court has not passed on any "contemplatiun of death" case since 1938. However, from the biginning of 1939 to date, 10 district court decisions were all affirmed by the circuit courts of appeals and of $S$ Buard of Tax Appeals dccisions which were taken up, only one, Denniston v. Commissioner, 106 In. 12d) 925 (C. L. A. 3rd, 1939), was reversed, by the Third Circuit. That decision has probably been interred by the same court in Commonwealth Trust Co. of Pittsburgh v. Driscoll, 137 F. (2d) U53 (C. C. A. 3d, 1943), cert. denicd, 321 U. S. 764 (1944). It is further interesting to nute that the Government did not prosecute appeals on the contemplation of dcath issue from any of the fifty-odd Board or Tax Court decisions which since 1938 have bsen decided in favor of the taxpayer. It is understood that this is in line with the policy of the Department of Justice not to appeal from decisions which are based on a finding of fact.

The soundness of this attitude is borne out by the decisions. In a recent case, IfcGrev's Estate v. Commissioner, 135 F. (2d) 158,150 (C. C. A. Uth, 1943), the Sisth Circuit said:

"The Supreme Court held, in Colorado Nat. Banls v. Cummiscioner, 305 U. S.

23 (1938), that the decision of the Board of Tax Appeals as to whether a trancier was in contemplation of death is a question of fact upon which the desicion of the Board, if supported by substantial evidence, is conclusive."

Statements to the same effect may be found in Smails y. O'Mlalley, 127 F. (24) 410,412 (C. C. A. Sth, 1942) ; Northern Trust Co. v. Commissioner, 11 b F. (2d) 96,93 (C. C. A. 7th, 1940); Bradley v. Smith, 114 F. (2d) 161,164 (C. C. A. 7th, 19i0); Blalieslce v. Smith, 110 F. (2d) 364,366 (C. C. A. 2d, 1940); Oliver v. Eell, 103 F. (2d) 760,762 (C. C. A. 3d, 1939); Buckminster v. Commissioner, 4 Prentice-Hall 1944 Fed. Tax Serv. I62,770 (C. C. A. 2d, 1944). The last mentioned case and Gross v. Ruthensies, 4 PrenticeHall 1944 Fed. Tax Serv. $\ 62,689$ (E. D. Pa. 1944), deal primarily with the typs of a idence admissible in contemplation of death cases. 
easy. ${ }^{14}$ Almost always, however, the circumstances indicate that the decedent'may have been actuated by mixed motives. In the leading case of United States ${ }^{\prime}$. Wells ${ }^{15}$ the Supreme Court in 1931 stated it to be the duty of the courts in that situation ${ }^{16}$ "to detect the dominant motive." It is trute that Mr. Chief Justice Hughes in discussing the statute said that its "dominant purpose is to reach substitutes for testamentary disposition and thus to prevent the evasion of the estate tax." But it is submitted that a reading of the opinion as a whole makes it quite clear that the test for determining whether the transfer was in fact such a substitute must be found in the transferor's dominant motive. Indeed, the Treasury accepted this construction, for in its regulations adopted in 1934 "due to the new light thrown upon the meaning of 'transfer in contemplation of death' as elucidated in United States v. Wells," ${ }^{17}$ it stated that "if the transfer results from mixed motives, one of which is the thought of death, the more compelling motive controls." 18

- The 1940 Amendment of the Regulations. Nothing in the language of the $W$ ells case, however, justifies the change in the regulations made on March 5, 1940.19 The regulation now reads:

14. See, however, the discussion in Trust Co. of Georgia v. Allen 55 F. Supp. 269 (M. D. Ga. 1944), where the court rejected the Government's contention that a transfer made for the sole purpose of avoiding estate tax is necessarily made in contemplation of death.

15. 283 U. S. 102 (1931).

16. Although in 1920, at the time of the questioned transfers to his wife and children, decedent was a man of over 70 and was suffering from both asthma and a severe ulcerative colitis, the Court looked beyond these intimations of death motivation to his lifelong practice of making liberal gifts to his family and there found the primary inducement. Since the transfers took place in 1920 , they were subject to the rebuttable two-year presumption and not the conclusive one attacked in Heiner v. Donnan, 285 U. S. 312 (1932).

17. C. C. H. Fed. Inher. Tax Serv. \3423.015 (1943).

18. U. S. Treas. Reg. 80 (1934 ed.), Art. 16.

19 This is true, a fortiori, of the only contemplation of death case decided by the Supreme Court since the $W$ ells case, Colorado National Bank v. Commissioner, 305 U. S. 23 (1938). The Board had found a controlling life motive in decedent's desire to put in trust for the benefit of relatives a part of his estate so that he might feel more free to indulge his penchant for stock market speculation without endangering all of his fortune and hence the future welfare of the natural objects of his bounty. The Tenth Circuit Court of Appeals found this too hard to swallow since the donor was 80 when he established the trust, the terms of which corresponded with his will. The Supreme Court, however, in its turn reversed. Probably some of the justices who voted to do so did so primarily because they thought the appeilate court had exceeded its authority in overthrowing the determination of the Board on a question of fact where there was evidence to support the Board's finding. The decision purports to reiterate the test of the Wells case enunciated seven years earlier. Mir. Justice Black, however, in his dissent asserted that the majority had disregarded an essential part of that test, i.c., that the donor's motive was of the kind "which leads to a testamentary disposition." Id. at 30. If anything, the Colorado National Bank case must be regarded as weakening the importance of the test laid down in the Wells case. See (1940) 88 U. of PA. L. REv. 371. 
"A transfer in contemplation of death is a disposition of property" prompted by the thought of death (though it need not be solely so prompted). A transfer is prompted by the thought of death if it is made with the purpose of avoiding the tax, or as a substitute for a testamentary disposition of the property, or for any other motive associated with death." 20

It is understood that the Bureau of Internal Revenue made this change in the regulations because of the decision in the st-called Astor case..1 This was done in order (1) to state specifically that where a transfer was made for the purpose of avoiding estate tax, such a transfer was made in contemplation of death; and (2) to eliminate from the regulations the language that where there are "mixed motives ... the more compelling motive controls." Thus, the regulations now state that a transfer is in contemplation of death if it is prompted by any motive assuciated with death, even though it may also be much more strongly prompted by other motives clearly associated with life. Since this startling modification is thought to be justified by the Astor decision it seems appropriate briefly to review that famous litigation.

The Astor Casc. William IValdorf Astor, a British subject and resident. had in New York property worth about $\$ 93,000,000$. When he died he had left in this country $\$ 1,300,000$.: The rest he had transferred to his children without payment of any American transfer tax. Befure 1916 he had made gifts to his children outright or in trust in excess of $\$ 24,000,000 .^{23}$ Early in that year he created for them an additional trust uf perstmalty of over $\$ 23,000,000$. The Government vainly attempted to have this fund subjected to estate tax on grounds other than cuntemplation of death.". After this gift the bulk of Mr. Astor's remaining property in the Lnited States consisted of real estate. On August 15, 1919, at the age of 71 he further created two irrevocable trusts in faror of his sons to which he conveyed in equal shares $\$+6,000,000$ worth of American real estate which practically disposed of the balance of his holdings in the Linited States. He died two months later. ${ }^{25}$

20. T. D. 4966, 1940-1 Cum. Bull 220, amending U. S. Treas. Keg. 80 (1937 ed.), Art. 16.

21. Farmers Loan \& Trust Co. v. Bowers, 98 F. (2d) 794 (C. C. A. 2d, 1938), ccrt. denied, 306 U. S. 648 (1938), motion to extend time for reh. denicd, 307 U. S. 651 (1939), reh. denied, 308 U. S. 334 (1940), second petition for reh. denicd, 310 U. S. 657 (1940).

22. See $15 \mathrm{Am}$. Fed. Tax R. 663, 668 (S. D. N. Y. 1931).

23. See Farmers Loan \& Trust Co. v. Bowers, 68 F. (2d) 916, 917 (C. C. A. 2d, 1934), cert. denied, 293 U. S. 565 (1934), 296 U. S. 649 (1935), 299 U. S. 582 (1936).

24. "Farmers Loan \& Trust Co. v. Bowers, 29 F. (2d) 14 (C. C. A. 2d, 1923).

25. See note 21 supra. 
The Government not unnaturally attacked the transfer as made in contemplation of death. In the first district court decision, ${ }^{20}$ Judge Caffey, remarking rather optimistically, it now appears, that "prior to the decision of the Wells case in April last there was confusion as to what was meant by the phrase "in contemplation of death," " ${ }^{27}$ applied the new rule laid down in that case, that "the transfer is not taxable unless the thought of death was the impelling cause of the transfer." After a lengthy and detailed review of the evidence, he found that decedent had been primarily motivated by a desire to reduce his income taxes and to escape a threatened British capital levy.

The Second Circuit reversed. ${ }^{28}$ Judge Manton found that each of the motives, that associated with life and that associated with death, was equally controlling and compelling. Apparently realizing, however, that his ruling went beyond the $W$ ells case, he thought it necessary to distinguish the latter, saying:

"When the Wells case said that the motive to escape estate taxes must predominate, it was in a situation where the settlor's other motive was to provide for his children, not to escape income taxes. That in our opinion should color the language. . . . The law does not actively foster such a purpose ; it regards it in a different light from providing for children, developing their financial responsibility, or enjoying leisure in old age. ... But a purpose to avoid income taxes is not of that kind ; it is excusable, but it cannot positively justify a gift otherwise taxable. We do not believe that the language in the Wells case meant to say so, and for that reason it seems to us immaterial that on the evidence it was impossible to know whether the settlor was more concerned about his estate taxes or his income taxes."2g

On remand to the District Court a jury, being charged that if it found the "motive of avoiding estate tax played a "substantial part" it must hold the trànfers to have been made in contemplation of death, brought in a verdict for the Government. ${ }^{30}$

When the case again went up on appeal to the Second Circuit, Judge Augustus N. Hand reiterated the conclusion that ignoble motives associated with life, such as the saving of current taxes, ${ }^{31}$ were not within the

26. This decision appears to be reported only at $15 \mathrm{Am}$. Fed. Tax R. 663 (S. D. N. Y. 1931).

27. Id. at 665 .

28. See note 23 supra.

29. Farmers Loan \& Trust Co. v. Bowers, 68 F. (2đ) $916,924^{\prime}$ (C. C. A. 2d, 1934).

30. This decision seems not to be reported, but entertaining excerpts from the colloquy between District Judge Patterson and the jury, wrestling with the meaning of "a substantial part," are set forth in the decision of the Second Circuit when the case again went up on appeal. $98 \mathrm{~F}$. (2d) $794,796-7$ (C. C. A. 2 d, 1938).

31. Tax consciousness with respect to taxes other than estate taxes seems, on occasion, to be a factor of some influence in contemplation of death decisions. See Estate of 
ambit of the rule of the $W$ clls case, asserting that "these motives differ greatly from the beneficent purposes listed in the Wells case and are neither included in the statute as grounds of exception, nor made such under any decision." 32

When making this statement, Judge Hand apparently overlooked the decision of the Supreme Court rendered three years earlier-but after the first Astor appeal-in Beckcr a'. St. Louis Union Trust Company ${ }^{33}$ in which the aroidance of high surtaxes on the decedent's income was one of the life motives on which the Court based its decision in faror of the taxpayer. True, in that case the saring of other than estate taxes was not the sole life motive. But in Estate of John B. Waterman ${ }^{34}$ the Board of Tax Appeals held for the taxpayer solely on the ground that his decedent's motive was to minimize income taxes. And the Second Circuit itself, in its recent decision in City Bank Farmers Trust Company a'. McGou'an," when listing "life motives" described by the Supreme Court, includes "the desire to keep down the donor's surtaxes on his income," citing the St. Louis Union Trust Company case. ${ }^{30}$ This is a somewhat belated recugnition of the fact that the Supreme Court does not separate a goat called "saving of income taxes" from the milkwhite sheep identified as "benteficent purposes." It seems clear, then, that the actual ground on which the Astor case was decided was not sound when the decision in the second Astor appeal was rendered, has not been accepted as a precedent by any cuurt, and would not today be followed by even the Second Circuit.

Nevertheless, the more generally phrased considerations enunciated by that court in both of the Astor appeals, rejecting the "duminant motive" test, have had some influence in other fields of tax law ${ }^{37}$ and a direct effect

Adolph J. Koch, C. C. H. Dec. 13,128(M) (TC mem. 1943), affd, C. C. A. Tth, Lec. 11, 1944; Estate of Henry Monroe Springer, 45 E. T. A. 541 (1941), acd, 1942-1 Cl'us. Burx 15; Buckminster v. Commissioner, 4 Prentice-Hall 1944 Fed. Tax Srr: T 62,770 (C. C. A. 2d, 1944); if. Estate of John Rowley Gillingham, C. C. H. Dec. 12,424-D (BTA mem. 1942).

32. Farmers Loan \& Trust Co. v. Bowers, 98 F. (2d) 794, 798 (C. C. A. 24, 1933).

33. 296 U. S. 48 (1935).

34. C. C. H. Dec. 12,220-D (BTA mem. 1941).

35. 142 F. (2d) 599 (C. C. A. 2 d, 1944), aff'g 43 F. Supp. 790 (W. D. X. Y. 1942).

36. See sitpra note 33 .

37. Thus, speaking of another section of the Internal Revenue Code undur which purpose is the factor which determines the incidence of the tax, the First Circuit in Chicago Stockyards Co. v. Commissioner, 129 F. (2d) 937, 947-8 (1942), said:

"It has been held that the tax under $\$ 104$ cannot be aroided unless the corporation succeeds in establishing that the purpose of the accumulations was 'wholly other than that of preventing surtax unon its shareholders-not only' that there was another purpose, but that there was a complete absence of the purpose ... Perhaps this is too strong a statement; but it is clear. that $\$ 104$ would apply if in the totality of reasons which induced the continuing of the accumulations the forbidden ngotive of surtax avoilance played a sub- 
on the regulations concerning transfers made in contemplation of death. This is traceable to the Government's Brief in Opposition to the Petition for Certiorari in that litigation, where the argument was made:

"... In the Wells case, the Court was dealing with a situation where there was only a single motive, and that was one associated with life. If the $W$ ells case applies as well in the case of a complexity of motives, it certainly requires that all of the motivating factors-the motive in its entirety-must be given effect. The statute requires the inclusion in the gross estate of transfers made in contemplation of death, not merely those made solely in such contemplation. Consequently, it would seem to follow that, where transfers are motivated by a death purpose, they fall within the ambit of the statute, although it may be that the decedent also intended to subserve some life purpose thereby. To paraphrase the language used by the Court, the purpose of Congress is not to be thwarted by a rule which makes the final criterion of taxability that the transfer be made at least as much, or more, in contemplation of death than in contemplation of life." 38

To this rather strained attempt to get away from the admonition of the Wells case that "there is no escape from the necessity of carefully scrutinizing the circumstances of each case to detect the dominant motive" (and, surely, the use of the word "dominant" inevitably implies a weighing of the various motives) the following footnote was appended:

"If we are correct in this, then Article 16 of Regulations 80, which were promulgated under the 1926 Act, to which the petitioner refers, is in error in assuming the $W$ ells case to hold that, where one of the motives is the thought of death, the more compelling motive controls. This is apparently based upon a statement of the Court found upon page 119 of the report of that case to the effect that 'The gratification of such desires (to independently establish children with competencies, etc.) may be a more compelling motive than any thought of death'." 39

Denial of certiorari was apparently interpreted as approval of this disavowal of the Government's own regulations, for the change therein was

stantial part. Cf. Farmers' Loan \& Trust Co. v. Bowers, 2 Cir., 1938, 98 F. (2d)

794, 798 (C. C. A. 2d, 1938) ceriorari denied, 1939, 306 U. S. 648 . . ."

The Circuit Court of Appeals nevertheless found for the taxpayer. The Supreme Court reversed, 318 U. S. 693, 699 (1943), saying that it is sufficient if the purpose to avoid surtax upon the corporation's shareholders "induced, or aided in inducing" the continuance of the practice of accumulating earnings and profits.

.38. Brief for Appellee in opposition to the Petition for Certiorari, p. 20, Farmers Loan and Trust Co., see note 21 supra. (Italics as in original.)

39. Ibid. (Italics as in original.) 
made not long after the Astor litigation had finally ended. ${ }^{40}$ But, although the new regulation has been in force since Mirch 5, 1940, the courts and the Board have continued to decide cases on the basis of the "dominant motive" and only two decisions have been found in which the new regulation has been noticed. Even there it was not followed, for in Estate of B. H. Kroger ${ }^{41}$ the Tax Court also found a "dominant motive," and in Trust Company of Georgia z". Allin a a district court flatly rejected it as in conflict with the $W$ ells case.

In the Trust Company of Georgia case the decedent made outright gifts in 1925 and again in 1934 to one of his children of $\$ 100,000$ and simultaneously made gifts of like value in trust for two other children because of past experience in their mishandling of prior gifts. The donor died at 82 in 1938 owning about a million dollars. Under the trust instruments he had reserved certain powers which he released in 1937 when for the first time advised that under the City Bank Furmers Trust Company case ${ }^{43}$ the gifts remained a part of his estate for estate tax purposes. In a well reasoned opinion, the court held that the release was not made in contemplation of death because clearly the original gifts had not been made in such contemplation and by the release the decedent was merely effecting his original intention of taking the property out of his estate. It concluded that:

"the 'motive' intended by the statute and to be regarded by the courts as controlling is not a motive to avoid estate taxes but is a motive to make a testamentary disposition growing out of special considerations in the donor's mind affecting the probability of his death." 4

The court flatly asserted:

"A desire to avoid [estate] taxes has no legal effect and it has no probative value even as evidence of special concern absut death, because in any transfer such a desire exists equally whether the thought of death is special or general." 15

It therefore rejected the Government's contention, based on the amended regulation, that a transfer made for the purpose of avoiding estate tax is necessarily in contemplation of death, saying:

40. Petition for rehearing was denied, 308 U. S. 634 (1939). The attorneys for the Astor estate made further strenuous efforts to obtain a Supreme Court review. See note 21 supra.

41. C. C. H. Dec. 13,488(MI) (TC mem. 1943), aff'd, C. C. A. 6th, Dec. 4, 194.

42. 55 F. Supp. 269 (M. D. Ga. 1944).

43. 296 U. S. 85 (1935).

44. Trust Co. of Georgia v. Allen, 55 F. Supp. 269, 274 (11. D. G2. 1944).

45. Id. at 270 . 
"That Regulation is broad enough to include the general expectation of death and is, therefore, in partial conflict with the case of United States v. Wells . . . which holds that the words in contemplation of death do not refer to the general expectation of death which all persons entertain'." 46

In reaching its conclusion in Trust Company of Georgia v. Allen the District Court relied on Denniston v. Commissioner, a Third Circuit case holding that a desire to avoid estate taxes "standing alone . . . cannot be deemed conclusive of a mental state such as is contemplated by the statutory phrase 'contemplation of death'." 47 It may be doubted, however, whether the Denniston case is still good law in the Third Circuit in view of the per curiam affirmance in Commonzealth Trust Company of Pittsburgh v. Driscoll ${ }^{48}$ of a district court opinion holding that where no reason could be discerned for a transfer other than the intention of avoiding estate tax "naturally the transfer must have been made in contemplation of death." Similarly, in Estate of Frank A. Vanderlip, ${ }^{40}$ the full amount of the proceeds of assigned life insurance were held includible in the assignor's estate where it was stipulated that the transfer was made for the purpose of saving estate taxes "but not otherwise in contemplation of death." Since the loan value of the policies in question had been exhausted at the time of the assignment, it would seem that the saving of estate tax was the sole motive for the transfer. Hence neither the Commonzerealth Trust Company nor the Vanderlip case can be interpreted as inferentially supporting the regulation which lays down the test that the mere presence of a motive associated with death taints the transfer regardless of the strength or "dominance" of concurrent motives associated with life.

Test of. "Substitute for a Testamentary Disposition." Presumably because the courts have continued to follow the Wells case test, the Government has been trying to wean them away from their preoccupation with the "dominant motive" by stressing the test that a transfer is in contemplation of death if it is made as a substitute for a testamentary disposition. In the Wells case the Supreme Court stated that the purpose of the statute was to reach such substitutes and that, as a transfer might otherwise have all the indicia of a valid gift inter vivos, the differentiating factor must be found in the tranferor's motive. The amended regulation, however, has been framed ambiguously. Its precise wording on this point is :

46. Ibid.

47. 106 F. (2d) 925,928 (C. C. A. 3d, 1939).

48. 50 F. Supp. 949 (W. D. Pa. 1943), aff'd, 137 F. (2d) 653 (C. C. A. 3d, 1943), ccrt. denied, 321 U. S. 764 (1944).

49. Estate of Frank A. Vanderlip, 3 T. C. 358 (1944). The information as to the stipulation was obtained from the record. 
"A transfer in contemplation of death is a disposition of property prompted by the thought of death (though it need not be solely so prompted). A transfer is prompted by the thought of death if it is made ... as a substitute for a testamentary disposition of the property ...." 50

This language may be interpreted to mean :

(1) A transfer is prompted by the thought of death if it is made with the intent that it shall serve as a substitute for a testamentary disposition.

(2) A transfer is prompted by the thought of death if it has the effect of serving as a substitute for a testamentary disposition.

The latter interpretation avoids the difficulty of ascertaining the donor's motive. It is easy to understand why the Government should wish to avoid the necessity of establishing such a motive, which the donor may have attempted to conceal or may not even have been clear about himself. ${ }^{\text {I }}$ It is submitted that the second paraphrase is a distortion of the rule of the $W$ ells case. Yet this appears to be the line of attack presently used by the Government in some cases. For example, in Koch '. Commissioner," on an appeal by the taxpayer to the Ninth Circuit, the Government argued in its brief as follows:

"General thoughts or expectation of death obviously lose their characteristics as such if they become so specific as to motivate transfers. Indeed, it is this fact which differentiates general thoughts of death from the 'contemplation of death' to which the statute refers. This is the rationale of the $I /$ clls case. It is for this reason that it has become important to ascertain whether the thought of death has become an activating factor in making the transfer; and that it has become such factor is said to be established if the decedent's purpose is to make a transfer which is in its nature a substitute for a testamentary disposition." 53

It is true that this argument pays lip service to the $W$ clls case. But note that once it is established that the nature of the transfer is such as to be a substitute for a testamentary disposition (for example, a gift to issue per stirpes), then, under the above reasoning, the decedent's death purposa must be assumed regardless of any other circumstances such as age or health and regardless of any number of other proved and weighty" "life motives"; for, be it remembered, under the amended regulation the

50. See supra note 20.

51. See 1Ir. Justice Stone's dissent in Heiner v. Dunnan, 285 U. S. 312, 332, 342 (1932).

52. C. C. H. Dec 13,12S(1I) (TC mem. 1943), aff'd, C. C. A. 9th, Dec 11, 194.

53. Brief for Appellees, Koch v. Commissioner, C. C. H. Dec. 13,128(21) (T.C. mem. 1943). 
presence of a "death purpose," no matter how relatively unimportant it may have been, is sufficient to bring the transfer within the sweep of the statute.

The Government's approach which, when viewed realistically, looks to the effect of the transfer and not to the purpose impelling it, will presumably be buttressed by the recent amazing decision of the Second Circuit in City Bank Farmers Trust Company v. McGowan. ${ }^{54}$ In that case transfers made by court order out of the estate of an incompetent, who of course could have no purpose or intent, were adjudged to have been made in contemplation of death because they reflected an intestate distribution of the incompetent's assets rather than the inter vivos gifts which she presumably would have made had she remained sane: Indeed, the small proportion of the challenged transfers corresponding to the annual allowances which the decedent had made to her children before she became mentally ill were expressly excepted from the scope of the decision. The court, in reaching what appears to be an erroneous conclusion, indulged in some rather peculiar reasoning in order to attribute to the lunatic a motive associated with death. So at least thought Judge Swan, who said in his dissent:

"In the case at bar the orders of the New York Supreme Court embodied findings that if the incompetent were in possession of her mental faculties she would have made the allowances ordered by the court. It is against this background that the problem must be considered.

"My brothers recognize that 'obviously the incompetent herself could have had no intent of any kind' with respect to the allowances ordered by the state court. They then ascribe to her 'the intent of the court'; not, however, the intent expressed in the court's finding that she would have made the gifts, if competent, but an intent to make 'such gifts as she would have made, if for the moment lucid, but with the prospect of imminent incompetency before her.' This seems to me the veriest fiction. Fictions, of course, have frequently been employed in legal reasoning, but not so far as I am aware, to extend the coverage of a taxing act beyond its letter.... It is true that the sums paid out pursuant to the state court's orders decreased the amount of the incompetent's estate at death, and in so far as they were paid to her next of kin may perhaps be characterized as the 'substitution' of a gift inter vivos for an 'intestate disposition.' But, as my brothers recognize, gifts to next of kin are not necessarily transfers in contemplation of death-it turns on the donor's dominant motive. United States v. Wells. . . Concededly the incompetent herself could not 'contemplate' death. The state court which directed the payments to be made did not purport to make transfers in contemplation of death and had no legal power to do so. It cannot make testamentary dispositions for the incompetent, N. Y. Civ. Prac. Act $\$ 1383$; and in mak-

54. 142 F. (2d) 599 (C. C. A. 2d, 1944), cert. granted, 65 Sup. Ct. 65 (U. S. 1944). 
ing allowances to his family it 'does not do this because, if the lunatic were to die tomorrow, they would be entitled to the distribution of his estate ... .,' but because 'the court will not refuse to do, for the benefit of the lunatic, that which it is probable the lunatic himself would have done.' Per Lord Elden in Ex Parte Whitebread, 2 Mer. 99, 102-3. Whether Congress would wish to impose an estate tax on gifts made out of an incompetent's surplus income by court order for the support and education of his family seems to me the merest surmise. At any rate, it has not said so in language justifying the courts in so holding." "

While the Treasury may find support for its extreme "in the nature of a testamentary disposition" theory in the result of this case, yet it should be observed that even the majority did not go along completely with the Government's reasoning evidently presented at the oral argument. Judge Learned Hand, after reviewing statements made in the Wells case concerning various sorts of motives, ${ }^{\text {BD }}$ said:

"Thus, if the gift be a 'substitute' for a 'testamentary dispusition,' and if the only motive be a desire to anticipate the benefit which the donee will eventually get by such a disposition, it might seem to fol=

55. 142 F. (2d) 599,604 (C. C. A. 2d, 1944).

56. Judge Hand mentions as motives associatcd with life, the desire to accustom the donee to the management and responsibility of property, United State v. IVells, 283 U. S. 102 (1931) ; the desire to make him independent, or to keep down the donor's surtases on his income, Becker v. St. Louis Union Trust Co., 296 U. S. 48,52 (1935); and the desire to escape the possible consequences of the donor's own speculatiuns, Culuralo Nistional Bank v. Commissioner, 305 U. S. 23, 26 (1938). Other purposes which have bren approved by the courts and the Board of Tax Appeals as being associated with life are the awidance of state personal property taxes, Estate of Jessie H. Rand, 36 B. T. A. 1160 (1937), 650 , 1938-1 Cuar. Burl. 25; Taft v. Commissioner, 33 B. T. A. 671, afi'd th another foint, 92 F. (2d) 667 (C. C. A. 6th, 1937), 304 U. S. 351 (1938); the transier uf [rengrty in settlement of litigation, Delaware Trust Co. v. Handy, 53 F. (2d) 1042 (D. Dal. 1931), aff'd on certified constifutional qutcstion, 285 U. S. 352 (1932); Daisy Christine Pottersun, Executrix, 36 B. T. A. 407 (1937), acq. and nonacq., 1935-1 Cus. Bur. 23, 52; the settlement of a family dispute, Polk v. Miiles, 268 Fed. 175 (D. Md. 1920); the prutection of the decedent's property and the preservation of the income therefrom by a trust, against the possibility that he might become mentally incompetent in lis old age as had hagpensd to certain of his relatives, Chemical Bank \& Trust Co., Executor, 37 B. T. A. 535 (1933), acq. and nonacq., 1938-2 Cuns. Burn. 28 and 1939-1 Cus. Buln 31, arithdrating nonacq., 1938-2 Cum. BuLr 39, 57; a transfer in order to permit his sons to talie over his business for which purpose he had trained and educated them, Estate of Herbert G. Lowe, 38 B. T. A. 117 (1938); desire of a married woman to avoid friction with her husband arising from his interference in the management of her property, Dwight Whiting, at al., Trustees, 35 B. T. A. 100 (1936), nonacq., 1937-1 Cuxr. Burr. 53; the protection of the decedent's property from stock market speculations or other business hazards, Brown v. Commissioner, 74 F. (2d) 281 (C. C. A. 10th, 1934); Thomas C. Boswell, cl al., Exceutors, 37 B. T. A. 970 (1938), acq. and stort-acq., 1938-2 Cusr. Buzr. 26, 38; see also McFadden, et al., Executors v. United States, 20 F. Supp. 625 (D. Pa. 1937). 
low inevitably that it is made 'in contemplation of death.' Yet, if that be true, every present gift, actuated by an undifferentiated cesire to benefit the donee, is a gift 'in contemplation of death,' if only it is made to a person to whom the donor would have left the property on his death. In that event the gift tax covers only gifts which are not 'sübstitutes for testamentary dispositions,' and gifts, which, though they are such substitutes, are made with some 'dominant' purpose of the specific character which takes the gift out of the section. Possibly that may be the law, but certainly it has not yet been clearly so declared." 57

Influence of the Testamentary Disposition Test. That the courts recently, however, have been increasingly influenced by the fact that a transfer bears resemblance to a testamentary disposition is strikingly illustrated by two cases ${ }^{58}$ involving a pair of sisters, Miss Mary E. Barnard and Mrs. Alice B. Davis. Both lived in Grand Rapids, Michigan, and had sufficient property there so that each allowed the income on her other substantial holdings in Wayne County, Michigan, to accumulate, using it only occasionally for the purpose of making gifts to relatives or various institutions. At about the same time each transferred her Wayne County property to a separate trust, after having discussed the matter with the other and having employed the same lawyer to draft both instruments. The preamble of each instrument stated that the purpose of setting up the trust was to continue a long-established policy of making gifts. Miss Barnard was almost 84 when she made her trust and died within the two-year period mentioned in the statute. She was a retiring person who took no part in social or other activities. For some years prior to her death she suffered from arteriosclerosis and dizzy spells and was frequently visited by her doctor. Mrs. Davis was 82 when she created her trust and survived for 3 years and 3 months, dying unexpectedly after having attended church and dined at a Grand Rapids hotel the Sunday before. Unlike her sister, she was active and much interested in mission and church work. At the age of 84 she made a trip East to her girlhood home in Vermont, travelling alone. Yet in the Barnard case the Tax Court "readily concluded" that "the trust had its genesis in purposes associated with life," whereas in the Davis case which came before it three years later the transfer was held to have been made in contemplation of death. How can this divergence be explained when at least the same or possibly even reverse results seem more reasonable?

The deciding factor appears to have been that Mrs. Davis' trust instrument gave half the property to her son and the other half to a grandson

57. City Bank Farmers Trust Co. v. McGowan, 142 F. (2d) 599, 602 (C. C. A. 2d, 1944).

58. See note 2 supra. 
to be delivered to him at the age of 30 , or if he died earlier, then to his children, and in default of children, half to the son and the other half to the Board of Foreign Missions to be used for its establishments in Shansi and Angola. Her will, which antedated the trust deed by five years, left the residue to the same persons, on the same terms ${ }^{53}$ and with the same contingent remainders. Miss Barnard's will left numerous legacies to charitable institutions and relatives and named MIrs. Davis as the residuary legatee. Miss Barnard, a spinster, both under the trust and under her will transferred property to her closest living relatives and to charitable institutions which had won her interest and support during life, in other words, to the natural objects of her bounty. Mrs. Davis, a mother and grandmother, did the same. The only reason for reaching opposite decisions appears to be that, although all of the other usual indicia which are customarily reviewed in cases of this kind lean heavily in favor of Mrs. Davis, the sole fact that her inter vivos gift quite clearly uperated in anticipation of succession sufficed to render her transfer liable to estate tax. Had she given all of her Wayne County property to her son by deed and all of her Grand Rapids property to her grandson by will-ur possibly had she even altered the contingent remainders by substituting the Ileutians and Zambesi for Shansi and Angola-this octogenarian transferor might have fared no worse than the other.

Probably the amended regulation played its part. Since the Barnard opinion was promulgated in September 1940, it is reasumable to assume that the case was briefed and argued before the new regulation was published in March of that year. The change in the regulation, especially by importing into it the phrase "substitute for a testamentary dispusition," may be responsible for the centering of the Tax Cuurt's attention in the Davis case on that factor to the exclusion, apparently, uf every other.

This new construction of the statute which has been urgea by the Government has also made itself felt in contemplation of death cases invulving transfers of life insurance policies. Of course, every person who talies out insurance on his own life is, in a sense, contemplating death. Similarly every gratuitous assignment of life insurance may be considered "testamentary in character," since a life insurance policy usually is of much greater value if held until the death of the insured. Yet, until quite recently, the courts have applied the usual tests and have frequently found that such assignments were made because of motives associated with life. In Estate of Charles A. Bickerstaff ${ }^{\mathrm{C} 0}$ the Tax Court unequivocally stated:

"It has never been suggested that the criteria which should guide us in our approach to this problem should be different, on account

59. The will qualifies the payment of cornus to the grandson at age 30 by the vords, "if he shows himself possessed of good character and habits (does not smoke or drinls or swear) and has sufficient business ability to take care of what is given him."

60. C. C. H. Dec. 12,871-O (TC mem. 1942). 
of the peculiar subject matter of the transfer, from those applicable to transfer of other property rights. ... Petitioner's decedent at the time he applied for the insurance written upon his life may have been motivated by the thought of the inevitable eventuality of death, as do all who apply for this form of insurance, but it does not follow that any motive connected with death prompted the later assignment." or

The court held against the Government because it found that decedent was motivated by a desire to put the policy out of his reach "and thus to protect his wife and children from any possibility of loss arising from his own improvidence or from any financial catastrophe which might befall him." 02 Several other recent cases involving assignments of life insurance policies were likewise decided in favor of the taxpayer. ${ }^{.3}$

In 1943, in First Trust \& Deposit Company v. Shaughnessy, ${ }^{64}$ however, the Second Circuit held that an assignment of life insurance to a trust was made in contemplation of death despite the fact that the beneficiary had, power to revoke the trust and to withdraw any policy and exercise any privilege of ownership reserved therein. The trust was created by the wifc of the insured at his behest shortly after his assignment of the policies to her. His purpose thus to save estate taxes was held the intent which determined the gift for purposes of the statute. The court found that there was no evidence that the reservation of powers to the wife was made because the decedent expected her to use them. "That he expected that she might do so," it said, "does not help to show that he regarded the power as of greater importance than his testamentary disposition." Since the creation of the trust was thought to be impelled only by a desire to avoid a tax which could not fall due before death, the court found that this was "nearly, if not quite conclusive, proof" that the reserved powers were not deemed as important as the post mortem disposition. Finally, the court observed that under such circumstances the condition of decedent's health and his state of mind toward death were immaterial. ${ }^{\text {t5 }}$

61. Ibid.

62. Ibid.

63. Boyle Trust \& Investment Co. v. United States, 43-1 U. S. T. C. ๆ10,021 (W. D. Tenn. 1943) (assignment made because of moral obligation and in furtherance of liberal gift policy); Estate of Charles Delany, 1 T. C. 781 (1943) (various motives and transfers made 14 years before death); Estate of Charles T. Smith, C. C. H. Dec. 12,950(M) (TC mem. 1943) (needy assignee borrowed on policies); Anna R. Marsh, Ex'rx, C. C. H. Dec. 12,411-F.(BTA mem. 1942) (transfer had been planned for years); Estate of Louis Baskind, C. C. H. Dec. 11,829-E (BTA mem. 1941) (decedent persuaded to assign policies in lieu of making gift of their cash surrender value).

64. 134 F. (2d) 940 (C. C. A. 2d, 1943), cert. denied, 320 U. S. 744 (1943).

65. This case was followed in Liebmann v. Hassett, 50 F. Supp. 537 (D. Mass. 1943), where decedent when in ill health assigned policies to his wife and died within two years. The court pointed out that decedent could not have intended that his wife, who was inde- 
Problems of Property Valuation. Even after it has been determined that a given transfer was made in contemplation of death, difficult problems of valuation remain. How, for example, should property so transferred be valued when at date of death (1) the same or similar property exists but is no longer owned by the transferee, or (2) the property no longer exists?

It is understood that the administrative practice of the Bureau with regard to valuing property transferred in contemplation of death is as follows :

(1) If the gift is made in cash, its value at the date of gift is talken as the value at date of death, regardless of whether it has been kept

pendently wealthy, would cash in a $\$ 50,000$ face value policy for its surrender value of $\$ 25,000$. It held, however, that only that fraction of the proceeds was includible in the gross estate which represented the pro rata part of the premiums paid by the decedent, relying on the provision of U.S. Treas. Reg. 80 , Art. 15, reading: "If the transferee has made additions to the property, or betterments, the enhanced value of the property dus thereto should not be included." The discussion in Estate of Frank: A. Vanderlin, 3 T. C. 358 (1944), indicates that a similar apportionment would have been made if some one other than decedent had paid part of the premiums.

Life insurance premiums normally are brought into the gross estate by Section 811 (g) of the Internal Revenue Code. They are wholly includible if received by decedent's executor and are includible, if received by other beneficiaries, to the extent of the amount which is equal to the percentage of the premiums paid by the decedent, or with respect to which decedent at his death possessed any of the incidents of ownership. Art. 8125 of U. S. Treas. Reg. 105 further provides, however, that life insurance not includible under Section 811 (g) may be includible under some other paragraph of Section 311. Referring to contemplation of death, the regulation, paraphrased, specifies:

Thus in the case of insurance on his own life which the decedent fully paid up prior to January 10,1941, the date of Treasury Decision 5032, and which he gratuitously transferred prior to such date in contemplation of death, the insurance proceeds are includible in his gross estate under Section S1I(c).

This part of the regulation seems proper since the total value of the policy is attributable to the decedent's payments and because he assigned that total value when he transferred the policy in contemplation of death. The regulation continues:

Similarly, in the case of a decedent who never paid any premiums upon an insurance policy upon his life but possessed incidents of ownership therein (other than a reversionary interest), if he gratuitously transferred all rights in such policy in contemplation of death ... the proceeds are includible in his gross estate under Section S11(c).

This result seems incorrect. Suppose another person had paid $\$ 10,000$ in premiums up to the date of decedent's transfer in contemplation of death of the incidents of ownership. Thereafter such other might or might not continue paying premiums. The amount of proceeds includible in decedent's estate would therefore depend on payment made by another after decedent had released all interest in the policy. To state the proposition seems to display its incorrectness. It is submitted that the amount of proceeds includible in the estate in this situation ought to be determined by the value of what decedent gave up, and should not include those due "to additions or "betterments" made thereafter by" another. Cf. Liebmann v. Hassett, suspra. 
in a safe cleposit box, destroyed by fire, profitably invested or squandered. There do not seem to be any cases on this point, but it is understood that a few administrative settlements have been made on this basis.

(2) If the subject matter of the gift is property other than cash, then the value of that specific property at date of death is the amount includible in the gross estate. If the donee has disposed of the property given him, it is immaterial whether he did so at a profit or loss or whether he invested the proceeds fortunately or disastrously. There do not seem to be any cases on this point, but again it is understood there have been some administrative settlements along this line.

(3) An exception to (1) and (2) is that in the case of a transfer in trust, of cash or other property, the test is the value of the trust corpus at date of death. On this point there are at least two decisions.

Support for the "value at date of death" test can, perhaps, be found in Igleheart v. Commissioner ${ }^{66}$ in which the court said :

"The thing taxed is the transmission of property from the dead to the living. For the purposes of the tax, property transferred by the decedent in contemplation of death is in the same category as it would have been if the transfer had not been made and the transferred property had continued to be owned by the decedent up to the time of his death. As to the property so transferred, as well as to property owned by the decedent at the time of his death, the measure of the tax is the value of that property at the time of the decedent's death. ${ }^{\text {or }}$

The principle of the Igleheart case may be summarized as follows: the property should be regarded as though it had, remained in the possession of the donor; anything which happens because of action by the donee is to be disregarded. ${ }^{68}$

By what reasoning, however, may a different standard of valuation be applied in the case of transfers in trust where not the date-of-death value of the original property transferred but the then value of the corpus furnishes the administrative test? The Bureau, it is understood, reasons that

66. 77 F. (2d) 704 (C. C. A. 5th, 1935).

67. Id. at 711 (emphasis supplied).

68. Support for this attitude can perhaps be found in some of the transferee liability cases. For instance, in Koch v. United States, 138 F. (2d) 850, 852 (C. C. A. 10th, 1943), the court said:

"Where the assets coming into the hands of a stockholder suffer a change in value, the creditor must take the trust as he finds it, securing the advantage of any increase and suffering any decrease, unless the stockholder is responsible for the decrease. Where the trust property has been used by the stockholder for his own purpose, or disposed of by him, he may be held personally. liable for the full value thereof." 
the transfer was not made directly to the donee, but for the benefit of the trust beneficiary, and that the subject of the gift was the trust fund rather than the individual securities put into the trust fund. If a distinction exists between a trust fund as property and the underlying assets, then the above quoted language from the Iglcheart case would seem to justify the second and third Bureau practices above. But this distinction seems tenuous. And, as a matter of fact, the trust is the only situation that has been passed on by the courts. A careful reading of the Iglehcart opinion and of that below ${ }^{69}$ shows that transfers in trust were involved, that the trustees had made reinvestments and that the Board was sustained in including in the gross estate the value at date of death of the assets of the trusts. It therefore seems that the Iglcheart case is authority only for the third Bureau practice, and that the language relied upon to support the second practice is mere dictum.

Furthermore, the Tax Court in Estate of B. H. Kroger, ${ }^{70}$ although again by way of dictum, has enunciated a rule quite contrary to the second Bureau practice. In that case decedent had made an inter vivos transfer to two trusts of $\$ 12,000,000$ face value United States Treasury notes and the Commissioner looked to the value of the substituted assets at date of death. The Tax Court upheld him, saying:

"The estate tax is imposed upon the value of the net estate as it exists at the date of death of the decedent. If the decedent had made an inter vivos gift in contemplation of death that property would have to be valued as of the date of death whether that value be more or less than at the date of gift; and if the property has becn converted into other property the value of such other properly al the date of death is the measure of the tar. The same rule applies where property is transferred to a trust in contemplation of death." 71

In view of this inconsistency between the Tax Court's opinion and Bureau practice, the problem of valuation must be regarded as wide open.

Of course, as a practical matter it is easy to understand the reason for the Bureau's valuation practices. It can readily determine the value of a trust fund at date of death, while frequently the tracing of what happened to cash or other property given away before death would present insuperable difficulties. Commingling and reinvestments would often defy analysis. Therefore, the Bureau has, one may suspect, adopted its practices solely for reasons of administrative convenience and has then, and not

69. 28 B. T. A. SSS (1933).

70. C. C. H. Dec. 13,438(M) (TC mem. 1943), affd, C. C. A. Gth, Dec. 4, 1944.

71. Id. at p. 17,501. The court also rejected a contention that the transferred proparty includible in the gross estate should be limited to the remainderman's interest valued as at the date of the transfer, saying: "The value of the transferred progerty at the date of death was not lessened by the fact that the decedent retained the income from the trusts for life, and it is the date of death which is the date of valuation." Ibid. 
too successfully, attempted to spell out some underlying legal justification. This may be all very well from the standpoint of facilitating the collection of revenue, but will often work out most unfairly from the taxpayer's point of view. For example, assume that decedent transferred in contemplation of death $\$ 100,000$ worth of prime bonds outright to his son and the same amount of such bonds to a trustee for the benefit of his daughter. The son and the trustee both sell the bonds and reinvest in, say, Kreuger \& Toll, which is worthless at date of death. Under the Bureau's practices nothing will be included in the gross estate because of the trust fund, but $\$ 100$,000 will be included by reason of the outright gift. If we concede to the Bureau that a method of administration which brings about such absurd results is due to the inherent unworkability of the statute, then we should obviously consider whether it is necessary to keep such a law on the books.

So also, if we concede that the Government may have found itself forced to go beyond the test laid down by the Wells case because of the frequent impossibility of discovering the donor's dominant motive (or, indeed, any of his motives), we should ask whether if a law, as construed by the Supreme Court, cannot be enforced, its retention is desirable.

\section{Conclusions}

When Mr. Justice Stone in his powerful dissent in Heiner v. Donnan ${ }^{72}$ defended the conclusive two-year presumption, there was no gift tax and, hence, as he demonstrated from the record, transfers probably but not provably in contemplation of death were likely to go wholly untaxed. But since June 6, 1932 the gift tax has again been on the statute books. It supplements the estate tax and follows the same general form. Since any gift inter vivos in excess of certain limited amounts is taxable under this law, it is difficult to understand why any provision seeking to reach a nebulous class of transfers called "in contemplation of death" is necessary. ${ }^{73}$ There was no gift tax in 1916 when that provision was first adopted. As a rebuttable presumption it proved unworkable. In 1926 when the short-lived original gift tax was repealed, the two-year conclusive presumption was introduced into the estate tax act. Shortly after it was held unconstitutional, the gift tax was again adopted. But Congress reverted to the rebuttable presumption with respect to transfers in contemplation of death. Its history since then has been as unhappy as that set forth in 1932 by Mr. Justice Stone. In an endeavor to remedy this situation the Treas-

72. 285 U. S. 312,332 (1932).

73. A further injustice, practically amounting to double taxation, results if a gift is taxed as an inter vivos transfer under the gift tax and is again subjected to a transfer tax under the estate tax because made in contemplation of death. This results from the inadequacy of the gift tax credit allowed under Sections 813(a) and 936(b) of the Internal Revenue Code. For a detailed explanation see Griswold, Cases and Materials on FedeRAI TAXATION (1940) 278. 
ury has indulged in administrative legislation which violates principles laid down by the Supreme Court. But wrong should not be cured by wrong. ${ }^{74}$ The contemplation of death provision has been a vehicle primarily for the harassment of taxpayers and has yielded little revenue to the Government. It is submitted that it should be repealed with retroactive effect except as to transfers made at a time when the gift tax was not in effect.

If Congress for any reason is unwilling to go that far, then it should re-enact a conclusive presumption, but should limit the "contemplation of death" provision to the period covered by that presumption. Such a presumption, if limited to the two-year period, might almost wholly obviate the difficulties which now beset taxpayers, as well as the Government's difficulties of valuation involved in following assets transferred many years ago. However, such a presumption, in order to approximate reality, should be limited to transfers made after a certain age and should include a standard more precise than the present statutory language which refers to "any transfer of a material part" of decedent's property. That the present Supreme Court would uphold such a statute seems quite probable. Although Heiner $\%$. Donnan ${ }^{75}$ has not been expressly overruled, the Court made it clear in Heli'ering i. Bullard is that due process of law is not violated by classifying transfers inter vivos with those at death.7

An analysis of the cases decided in the four and a half years beginning with 1940 shows that where the transfer was made at age 70 or over, it was held not in contemplation of death in 66 instances and taxable only in 25 . Where the donor's age was below 70,53 transfers were held nontaxable and the Government won in only 14 cases. Thus a conclusive presumption based on age 70 in all likelihood would not be disadvantageous to the Government even though it were coupled with a two-year maximum intervening between the transfer and death and a limitation that the value of the property transferred must exceed the value of the decedent's net estate at date of death. A conclusive presumption framed in these terms would have the additional merit of not flying squarely in the face of Heiner v. Donnan, in which the two-year interim was the sole criterion. But let it be reiterated that the advantage to all concerned of having such a conclusive presumption restored to the law will be wholly cancelled out unless that presumption is made the exclusive provision applicable to transfers in contemplation of death.

74. Compare Mr. Justice Douglas, dissenting in Cummissioner v. Harmon, 65 Sup. $C$. $103,105,106$ (U. S. 1944) : "One dubious decision does not of cuurse justify anohter."

75. 285 U. S. 312 (1932).

76. 303 U. S. 297 (1938).

77. Commentators agree that the case repudiates the reasoning of the Dornass decision. See Altman, Combining the Gift and Estate Taxes (1938) 16 TAx. MIAG. 259, 250; Lowndes, The Tax Decisions of the Supreme Court, 1938 Term (1939) ES U. of PA. L. REv. 1, 32. 